\title{
SAILING THE HERITAGE OF THE LAND OF DAHAB, NUBIA, THE SUN DOES NOT GO DOWN
}

Heba Ali Ahmed WAJIH *

Announcement Department, Faculty of Applied Arts, Helwan University, Egypt

\begin{abstract}
The research aims to revive the folk heritage in Nubia, as preserving the heritage is a basic necessity for peoples seeking to achieve their civilized self and prove their identity in their past and present, and the Nubian heritage is an important source of contemporary creativity from which artists, writers and poets draw inspiration from new creations to take their place on the cultural heritage map, and become a heritage that links the nation's present with its past And it works to increase its presence in the global cultural arena and the development of tourism, because the Nubian heritage is an integral part of the components of the Egyptian identity and an extension of the Pharaonic civilization, and it is of great value and importance as it is a basic form of development pillars in various arts, most notably Nubian architecture and homes.

Keywords

Sailing, Heritage, The Land Of Dahab, Nubia, The Sun.
\end{abstract}

\section{Introduction}

The same aesthetic features and several aspects of creativity such as Nubian handicrafts, jewelry, the social dimension of Nubia, its customs, language, traditions, timeless nature, climate that distinguishes it, and all the Nubian products whose creativity is inspired by that valuable heritage. Even finding a balance between protecting this heritage and tourism development. Therefore, preserving heritage clearly guarantees the continuity of the identity of nations and communities.

\section{The Land of Nubia:}

To the south of the city of Aswan and on the banks of the eternal Nile River for a distance of 20 kilometers until our borders meet the borders of Sudan, the Nuba region, which is the Land of Dahab, is located as it was called by the ancients thousands of years ago. That ancient love provided its long history with all its scents and faces The smiling brown woman who speaks to kindness and who enjoys a joyful and unique spirit, includes the Nubia area 38 village and Bandara Wahda and the village or Nubian city consisting of a group of distant dwellings, which are often located on the bank of the Nile or both banks and are called Naga. And longer the Nile The only transportation route in Nuba, as the conditions and nature of the region make it difficult to find suitable road for road transport in Sudan, and the Nubians use Nile ships and sail boats to move from one village to another. The Nubians are among the simplest and most welcoming peoples to strangers and guests, and ancient Egypt was able to build an ancient

*Corresponding author: appliedarts@a-arts.helwan.edu.eg 
civilization, rule with justice and spread love in the ancient world, and fought and fought with magnanimity and strength. And represented in the Nubian homes and decorations, ornaments and language and the language that is not written, the Nubian art, and the heritage represented in the distinctive clothes, architecture, cuisine, weddings and religious Nubian celebrations. The Nubian personality is characterized by simplicity and spontaneity, so you cannot read it from the pages of his face. Nubia occupied and is still a special place in the life of Egypt and the Egyptians, in the past and present, considering that it represents the southern gateway to Egypt. One of the largest, if not the largest, of all water dams, the High DamThe Nubia preserved it does not mean in reality stalemate or stereotyping, because one who contemplates this heritage will find that it consists of multiple elements that have their own characteristics that the groups that lived in the region expressed for themselves and their life and aesthetic value. "Land of Rabbani Beauty" is the voice of a penitent who resonates strongly, and his precise description of every inch in the land of gold, and the divine beauty, is clearly embodied in front of you. The place that resides at the end of the land of Al-Mahrousa is a treasure in all the meaning of the word, beauty covers every inch there, every minute detail on which the people of the country printed a magical touch in one way or another. From her heart, If you ask me about the virgin nature in Egypt, Nubia remains, its simplicity is the secret of its beauty, white boats dancing in the bosom of the Nile, houses colored to laugh at you, with a screen and a laugh from pure hearts, decorations and inscriptions inspired by their ideas by moving their history and art on the walls of their homes as if it were an open exhibition to the world, Nuba An Egyptian treasure, if it is still on a treasure, so let us feed Al-Hafa on the sea and sail in the heritage of its spot from the most beautiful parts of Egypt, "the Land of Dahab". Heritage Heritage is a great wealth among all peoples of the world as it consists of past values, customs and traditions, and the term heritage comes from the product of ancient civilizations that were inherited by modern generations as it consists of the experiences and ideas of the ancients it is considered a place without color or identity, where heritage represents an important part of the overall picture of society, as it contributes to strengthening the role of the economy and attracting tourists, and heritage is considered one of the important links that connect modern man with the past, and it is considered a symbol of human identity in general through which man is linked to his culture, and is considered history Nations and peoples that include all the cultures and ancient works that characterize our contemporary society, and it strengthens the human and social ties between people as the link lies with one origin and one culture. So heritage is the legacy that a father left to his son, and it is divided into two parts, physical or tangible, which are libraries, books, utensils, clothes, jewelry ... etc., and the second part is 
limited to influences and behaviors resulting from customs and values.

\section{The Nubian Heritage:}

The Nubia was characterized by many aesthetic and artistic aspects that were affected by the surrounding environment and resulted in innovations in the arts and industries. Inherited civilization from the environment in which he lives, the ideas of the Nubian creator are a harmonious fabric of beliefs, customs and social values, and the method of drawing symbols by which he expresses all of this is subject to recognized traditional lines, compiled by society, and on which he established standards through which he formed his artistic and aesthetic contents, and perhaps All this is what made the creativity of the Nubian man It is characterized by the diversity and richness of decorations and colors that depend on the variety of materials, as well as the multiplicity of methods of performance by which he carried out his works, especially the wicker works and the colorful wall decorative elements in the architecture. Hence, my role as a researcher and lover of Nubian art and searching for the Nubian identity was to try to restore this heritage and define it for modern society and preserve it from extinction. The Nubian people and the Nubian customs and traditions Despite the Nubians suffering from displacement and the deportation that occurred to them as a result of the floods and the flooding of their original homelands with the water of the dam, the continuous displacement processes have not lost the Nubians their identity, but still feel that they belong to their original homeland, and one of the most important features of the Nubian society is originality and strong adherence to the roots Dreaming, gentleness, honesty, honesty and giving peace to war, as the Nubians are known for their extreme hatred of violence and their love for fun and joy in all circumstances, and the manifestations of joy and joy are evident in their art, songs and dancing, and Nubians love life, and they dance and move their bodies to satisfy life in order to dance for them. For the Nubians, dancing is part of his personality., And all of his dances are inspired by his environment. Nubian customs and traditions are distinguished by their peculiarities and features that distinguish them from other Egyptian customs and traditions. The people of Nubia have been affected by their cultural heritage and culture that they acquired since ancient times, and this has been reflected in the Nubian personality. There are two factors that contributed to the Nubian being related to his customs and traditions and inseparable from it, the first factor is the closed Nubian language. On its family and not in circulation except among its owners only.

\section{Results}

- The Nubian heritage, when employed in various fields of art, may add richness and beauty, which increases tourism development and tourists 'demand to acquire things that bear the 
touches of this heritage.

- The Nubian must be given the right to restore its glory and its history and to preserve its heritage. Awareness and awareness of the value of our heritage must be increased, and society must be informed of it.

-Attention must be paid to the creative Nubian side and used in the style of buildings, accessories, costumes, engravings and other arts because of its aesthetic aspect that increases its value and richness, as Nubian artifacts are characterized by artistic richness in their general body as well as in the methods of their systems.

- Employing Nubian architecture derived from the Nubian heritage to enrich buildings.

- Giving attention to studies that deal with Nubian arts in order to preserve and record the Nubian heritage in its various forms and to monitor the variables affecting it. We must build places that open their doors to work and to preserve the Nubian heritage, and to train young people in our arts and crafts, so that they never die.

\section{References}

1. Marianne Inn. Decorations of the Nubian House, translated by: Fouad Muhammad Akoud, National Center for Translation, (12).

2. Mohab Darwish. History and effects of the seizure. Bibliotheca Alexandrina, (bits).

3. Mutawakkil Ahmad Amin. Nubia, Heritage, and Man through the Centuries. The Qurashi Foundation, (b.c.)

4. Ali Zain Al-Abidine. The art of crafting the Nubian folk kidney. Egyptian General Book Authority, (161)

5. Nahed Baba. Nubian motifs in architecture and wicker dishes, Wa'ad for publication and distribution, (2010) 6. Ghettas Muhammad. Photography in Nubia, Press of the Supreme Council of Antiquities, Ministry of Culture, Cairo (190).

7. Hashem Muhammad Hashem Nubian Customs and Traditions: Journal of Studies in the Humanities. Articles from periodicals

8. Souad Tantawy. "The Nubian House is an Art of Beauty." Country Echo.

9. Muhammad Ibrahim. "The revival of the Nubian heritage is not like racism."

10. Ismat Tawfiq. "Young". Nubian customs and traditions are well established in the land of Dahab. http: // shabab. ahram.

11. Mohamed Fouad El-Shazly. Realistic connotations of the Nubian heritage in Egyptian textile, http://www.shomosnews.com/?p=39640

12. Ahmed Salah. Nubian Art, Hadota Masriya, http://www.horytna.net/Articles/Details/177/86039/ The 8th International Conference, and 
Strategic Planning Summit.

13. Rasha Hussein El-sayed MOUSTAFA, A REVIVAL OF THE AQUEDUCT OF OLD CAIRO 'MAGRA AL AYOUN', International Journal of Multidisciplinary Studies in Heritage Research, Vol. 1, No. 2, 2018, pp. 1-9.

14. Amr Mohamed ATEF, ACQUISITION AND DISPOSAL POLICIES IN MUSEUMS, International Journal of Multidisciplinary Studies in Heritage Research, Vol. 1, No. 2, 2018, pp. 10-21.

Received: January 27, 2019

Accepted: March 10, 2019 